\title{
Qualitative analysis of activated sludge using FT-IR technique
}

\author{
Michał Kowalski ${ }^{1,2}$ (D) Katarzyna Kowalska ${ }^{3,4} \cdot$ Jarosław Wiszniowski $^{3} \cdot$ Jolanta Turek-Szytow $^{3,4}$
}

Received: 31 October 2017 / Accepted: 24 May 2018 / Published online: 9 June 2018

(c) The Author(s) 2018

\begin{abstract}
The ability to measure and control the composition of activated sludge is an important issue, aiming at evaluating the effectiveness of changes occurring in the sludge, what determines its usefulness to treat wastewater. In this research, diffuse reflectance infrared Fourier transform (FTIR-DRIFT) technique was used, which relies on measuring the reflectance of the powdered substance's surface layer and capturing spectra in range of infrared wave. First, spectra correlation table of the substances mostly occurring in wastewater was developed to assess the main components of the tested samples of activated sludge. The simplest compounds containing functional groups characteristic for particular chemical classes were chosen: peptides (peptone and albumin), fats (glycerin and fatty acids), carbohydrates (glucose and sucrose), nitrogen compounds $\left(\mathrm{NaNO}_{3}\right.$ and $\left.\mathrm{NH}_{4} \mathrm{SO}_{4}\right)$, sulfur compounds $\left(\mathrm{Na}_{2} \mathrm{SO}_{4}\right.$ and $\left.\mathrm{Na}_{2} \mathrm{~S}_{2} \mathrm{O}_{3}\right)$, silicate, etc. The spectra of those substances were captured and characteristic absorption bands for respective bonds in the function groups were assigned. Second, samples of activated sludge from lab-scale membrane bioreactors (MBRs), which purifies petroleum wastewater, were taken. Samples were properly prepared (lyophilization and homogenization) and their spectra were captured. During spectra analysis, previously developed correlation table was used. In obtained spectra of activated sludge, absorption bonds characteristic for amides, peptides, carbohydrates, fats, and aliphatic was identified. The spectra profile of the sludge sample from MBR feed with petroleum wastewater was slightly different from the control MBR sample's spectra. Intensity of bands in the area characteristic for aliphatic compounds and phenols was clearly higher. This study proves the usefulness of FT-IR technique to observe changes in the chemical composition of activated sludge.
\end{abstract}

Keywords FT-IR $\cdot$ Spectral analysis $\cdot$ Wastewater treatment $\cdot$ Activated sludge $\cdot$ Petroleum compounds

Jarosław Wiszniowski: Deceased.

Michał Kowalski

michal.kowalski@helmholtz-muenchen.de

1 Faculty of Energy and Environmental Engineering, Department of Air Protection, Silesian University of Technology, 22B Konarskiego Str., 44-100 Gliwice, Poland

2 Institute of Epidemiology, Helmholtz Zentrum München, German Research Center for Environmental Health, 1 Ingolstädter Landstr., 85764 Neuherberg, Germany

3 Faculty of Energy and Environmental Engineering, Environmental Biotechnology Department, Silesian University of Technology, 2 Akademicka Str., 44-100 Gliwice, Poland

4 The Biotechnology Center, Silesian University of Technology, 8 Bolesława Krzywoustego Str., 44-100 Gliwice, Poland

\section{List of symbols}

\section{Symbols}

$k \quad$ Constant

C Concentration

$K \quad$ Adsorption coefficient

$S \quad$ Diffraction coefficient

$R \quad$ Reflectance

\section{Greek letters}

$\nu \quad$ Stretching vibration

$\sigma \quad$ Deforming vibration

\section{Subscripts}

b Broad band

def Deforming vibration

DRIFT Diffuse reflectance infrared Fourier transform

DTGS Denaturated trigliceryn sulphate

FT-IR Fourier transform infra-red

$\mathrm{m} \quad$ Medium intensity band

MBR Membrane bioreactor

PES Polyether sulfone 


$\begin{array}{ll}\text { PSU } & \text { Polysulfone } \\ \text { s } & \text { Sharp band } \\ \text { s (m) } & \text { Multiple sharp band } \\ \text { skelet } & \text { Skeletal vibration } \\ \text { st } & \text { Stretching vibration } \\ \text { st as } & \text { Stretching asymmetric vibration } \\ \text { str } & \text { Strong intensity band } \\ \text { sy } & \text { Symmetrical vibration } \\ \text { w } & \text { Weak intensity band }\end{array}$

\section{Introduction}

The ability to measure and control the composition of the activated sludge is an important issue, aiming at assessing the effectiveness of the changes taking place in sediment to evaluate its usefulness in the wastewater treatment process. The previous studies conducted in Western countries, the European Union, the USA, and in Asian countries point to use for this purpose techniques of Fourier transform infrared (FT-IR) (Jiao et al. 2010; Kim et al. 2013; Reed et al. 2011; Zeng et al. 2016).

This technique is widely used for determination of composition in different media, such as water, soil, or plants. For example, it could be used to assess the changes in soil organic matter induced by irrigation with treated wastewater (Bernier et al. 2013; Parolo et al. 2017). Another application of FT-IR could be determination of metabolic profiles of Ulva lactuca plant, after exposure to oil diesel and gasoline (Pilatti et al. 2017).

This method is based on capturing spectra of the chemicals in the range of infrared wavelengths and allows determining the absorption bands of the substances, and thus identifying them. However, the effectiveness of the quantitative method determines the type of the chosen transformation method of the obtained spectrum during further analysis. Simple analysis allows only determining the occurrence of chemical compounds. More sensitive methods lead to compare the intensity of absorption bonds and specific spectra transformation gives an opportunity to quasi-quantitative estimation of chemical concentration.

In recent years, growing interest in the possibility of the use near infrared range (NIR) for diagnostic purposes in real time is observed. This method provides an opportunity to continuously monitor the sludge used in the process, or the composition of the influent to the waste water treatment plant (WWTP) as an early warning system. Specific probes mounted directly in the influent collectors of WWTP and coupled with the proper software could be a source of important information for the WWTP control. This method is non-invasive, fast, and relatively cheap, does not require chemicals, and does not produce any chemical waste. However, authors admit that the technique requires refinement and proper calibration, due to its sensitivity to changes in physical parameters such as temperature, degree of aeration, movement, or light scattering (Dias et al. 2008; Sarraguça et al. 2009).

Another method is the FTIR-attenuated total reflection (FTIR-ATR) - method of recording attenuated total reflection technique, which allows to the quantitative determination (directly on the membrane) of proteins responsible for the phenomenon of fouling (Delaunay et al. 2008; Pereira and Yarwood 1996). It requires special membrane material like containing in its structure polyether sulfone (PES) or polysulfone (PSU). Authors conclude that this method is useful to study the phenomenon of fouling in real time. The FTIR-ATR technique is also used to detection of changes occurring in the biofilm (Quilès et al. 2010). Research carried out concerning usage of Pseudomonas fluorescens shows that it is possible to use this technique to continuously monitor changes in metabolism starting from the early stage of the biofilm formation. Resulting spectra differ greatly among themselves, showing the different paths of development of the biofilm.

The aim of this study was to develop a rapid and reliable method for the evaluation of the activated sludge composition, using FT-IR techniques, and also identifying its main components.

\section{Experimental}

\section{Sample fixation}

In the first stage of the experiment, the spectra library of the compounds mostly occurring in municipal and coking plant wastewater was developed. The simplest chemical compounds, containing characteristic function groups for the specific classes of chemicals, were chosen. From the available reactants, only those with the highest purity were taken to the further analysis. Usually, spectra of the specific compounds were captured in three different concentrations ( $w / \mathrm{w}$ concentration, relative to $\mathrm{KBr}$, and optically transparent diluent) to assess the increase of intensity of absorption bands within concentration. With some of them, due to problems with dosage substances in liquid phase, spectra were captured in 1-2 concentrations. The list of model compounds with their purity and concentration is presented in Table 1.

Every sample was put into dryer set to $105^{\circ} \mathrm{C}$ and dried for at least $6 \mathrm{~h}$ to remove water. According to the adopted methodology, FTIR-diffuse reflectance infrared Fourier transform (FTIR-DRIFT) technique was used. Method was based on the instruction given by the producer of the instrument for the spectra capturing (PIKE Technologies 2009). Each dried 
Table 1 Model compounds used in the study, their purity, and concentration

\begin{tabular}{|c|c|c|c|c|}
\hline Compound & Purity & Conc. $1(\%)$ & Conc. $2(\%)$ & Conc. $3(\%)$ \\
\hline Acidic sodium carbonate $\left[\mathrm{NaHCO}_{3}\right]$ & - & 3 & 5 & 10 \\
\hline Albumin & - & 1 & 5 & 10 \\
\hline Ammonium sulphate $\left[\mathrm{NH}_{4} \mathrm{SO}_{4}\right]$ & PA & 1 & 5 & 10 \\
\hline Dry meat extract & - & 1 & 5 & 10 \\
\hline Glucose $\left[\mathrm{C}_{6} \mathrm{H}_{12} \mathrm{O}_{6}\right]$ & PA & 1 & 5 & 10 \\
\hline Glycerol $\left[\mathrm{C}_{3} \mathrm{H}_{5}(\mathrm{OH})_{3}\right]$ & Pure & 5 & 7 & - \\
\hline Lactose $\left[\mathrm{C}_{12} \mathrm{H}_{22} \mathrm{O}_{11}\right]$ & PA & 1 & 5 & 10 \\
\hline Oleic acid $\left[\mathrm{C}_{17} \mathrm{H}_{33} \mathrm{COOH}\right]$ & Pure & 3 & 6 & - \\
\hline $\mathrm{P}-30^{\mathrm{a}}$ (petroleum compound) & - & 5 & - & - \\
\hline Peptone G & - & 1 & 5 & 10 \\
\hline Phenol & Pure & 1 & 5 & 10 \\
\hline Potassium cyanide $[\mathrm{KCN}]$ & Pure & 1 & 5 & 10 \\
\hline Potassium thiocyanate [KSCN] & PA & 1 & 5 & 10 \\
\hline Silicate $\left[\mathrm{SiO}_{4}\right]$ & Pure & 1 & 5 & 10 \\
\hline Sodium carbonate $\left[\mathrm{Na}_{2} \mathrm{CO}_{3}\right]$ & Pure & 3 & 5 & 10 \\
\hline Sodium nitrate $\left[\mathrm{NaNO}_{3}\right]$ & PA & 1 & 5 & 10 \\
\hline Sodium nitrite $\left[\mathrm{NaNO}_{2}\right]$ & PA & 1 & 5 & 10 \\
\hline Sodium sulphate $\left[\mathrm{Na}_{2} \mathrm{SO}_{4}\right]$ & Pure & 1 & 5 & 10 \\
\hline Sodium sulphite $\left[\mathrm{Na}_{2} \mathrm{SO}_{3}\right]$ & PA & 1 & 5 & 10 \\
\hline Sodium thiosulfate (dry) $\left[\mathrm{Na}_{2} \mathrm{~S}_{2} \mathrm{O}_{3}\right]$ & PA & 5 & - & - \\
\hline Sodium thiosulfate (liquid) $\left[\mathrm{Na}_{2} \mathrm{~S}_{2} \mathrm{O}_{3}\right]$ & PA & 5 & - & - \\
\hline Sucrose $\left[\mathrm{C}_{12} \mathrm{H}_{22} \mathrm{O}_{11}\right]$ & PA & 1 & 5 & 10 \\
\hline Tween (detergent) & Pure & 4 & 6 & - \\
\hline
\end{tabular}

${ }^{\text {a }} \mathrm{P}-30$ was vacuum distillate of crude oil (boiling point $135-402{ }^{\circ} \mathrm{C}$ ) furnished by PKN Orlen oil refinery (Poland) (Wiszniowski et al. 2011) sample was rubbed in agate mortar. Then weighted out the specific mass and added powdered, dried potassium bromide (Spectroscopic grade KBr Graseby, Specac, UK) to obtain proper w/w concentration sample diluent. According to the methodology, to assess the changes in the intensity of absorption bonds of specific functional groups, chosen samples were prepared in concentrations $1-10 \%(w / w)$. Then, the DRIFT pellets were prepared to obtain homogeneous mixture.

\section{Spectra capturing}

Previously prepared pellets were put into the special holder (Easidiff diffuse, PIKE Technologies, USA) and placed in the Fourier transform infrared spectrophotometer BIO-RAD FTS 135 (BIO-RAD, USA), fitted with DTGS detector (Denaturated Trigliceryn Sulphate). Spectra were captured in mid-IR range 4000-400 $\mathrm{cm}^{-1}$, scanning resolution $4 \mathrm{~cm}^{-1}, 256 \mathrm{sin}-$ gle scans, and initial delay $300 \mathrm{~s}$ (for each sample). For the further analysis, Win-IR (BIO-RAD, USA) application was used. Obtained, averaged single beams for each sample were transformed into Kubelka-Munk (K-M) format, using as a background clear $\mathrm{KBr}$ (individual for each set of analysis). This method allows to indirectly assess the concentration, according to Eq. (1), where $k$-constant, $C$-concentration, $K$-adsorption coefficient, $S$-diffraction coefficient, and $R$-reflectance, and is preferred to samples weakly absorbing radiation (Džimbeg-Malčić et al. 2011; Hunter Lab 2008):

$k C=\frac{K}{S}=\frac{\left[1-R^{2}\right]}{2 R}$.

Obtained spectra were prepared for the further analysis. Some of them were smoothed using Sav-Golay method to enable identification of the occurring absorption peaks, without losing diagnostic information.

\section{Preparation of environmental samples}

During the next stage of the experiment, activated sludge from the lab-scale system consisting of twin, separate membrane bioreactors (MBRs) was sampled. Activated sludge used as an inoculum originated from municipal wastewater plant in Zabrze (Poland). One MBR was conducting the process of petroleum-contaminated wastewater treatment (MBR B), while the other (MBR A) was considered as a control. The experiment was lasting 122 days and was divided 
into five stages, according to increasing doses of P-30 $(0-1500 \mu \mathrm{L} / \mathrm{L})$. System was feed with synthetic wastewater, and medium for MBR B was enriched with dosing petroleum compound (P-30). P-30 is distillate of crude oil with boiling point $135-402{ }^{\circ} \mathrm{C}$, mostly consisting of poorly degraded aliphatic and aromatic hydrocarbons. Own research revealed the content of PAH, i.e., naphthalene, phenanthrene, anthracene, fluoranthene, and pyrene. The composition of P-30 fraction varies depending on the course of distillation. It is used as an addition to many industrial products, i.e., paints, impregnants, lubricants, etc. Activated sludge was collected from MBR A and MBR B approximately every 3 weeks.

Each time sampled $50 \mathrm{~cm}^{3}$ of activated sludge from MBR $A$ and MBR B. Then, filtered it and the residual was put into clear boxes and frozen. After this, activated sludge's samples were lyophilized in device Alpha 1-2 LD (Martin Christ $\mathrm{GmbH}$, Germany), for 5 days in vacuum 0.012 mbar. After that, samples were rubbed with dried $\mathrm{KBr}$ in ratio 15:300 (w/w), according to previously prepared model samples. For each sample, prepared three pellets consisting of $\mathrm{KBr}$ sample in the same ratio and analyzed using Win-IR application. After sampling, the replicates spectra for each sample were averaged.

\section{Results and discussion}

\section{Spectra library}

Based on captured spectra of the model compounds, and also their chemical structure (Mazurkiewicz and Salwińska 2000; Cygański 2002), comparing obtained results to reference correlation tables (Pretsch et al. 2000), spectra library was developed. It consists of obtained data of absorption bands of substances mostly occurring in wastewater. Library is shown in Table 2.

Wave numbers of the peaks corresponding with absorption bands and their characteristic shown in Table 2 were used during analyzing environmental sample's spectra. In case of developed spectra library, other publications concerning FT-IR analysis, using similar methodology, obtained roughly the same results, and peaks were observed in very similar regions (Quilès et al. 2010; Gulnaz et al. 2006; Wharfe et al. 2010; Cheftez et al. 2006; Amir et al. 2010; Kang et al. 2007; Guibaud et al. 2003).

\section{Lab-scale samples analysis}

During analysis of the activated sludge's spectra, observed characteristic infrared absorption bands. First of them was broad, mid-intense band between 3700 and $3300 \mathrm{~cm}^{-1}$. Clearly visible are maxims at $3300 \mathrm{~cm}^{-1}$, stretching vibration
O-H of hydroxyl group compounds (polyalcohol and saccharides), and at $3100 \mathrm{~cm}^{-1}, \mathrm{~N}-\mathrm{H}$ stretching vibration (proteins, peptides). In case of the samples from control MBR A, the relative intensity is increasing according to the duration of the experiment; it may reflect the adsorption of those compounds on the sludge. Whereas spectra obtained from MBR B (treating petroleum wastewater) reflect that samples from the beginning of the experiment have the strongest intensity at $3300 \mathrm{~cm}^{-1}$. This may suggest that petroleum compounds affect the adsorption capacity of the sludge.

Observed on $2950 \mathrm{~cm}^{-1}$ medium intensity, duplet band reflects alkyl chains (polyalcohols, saccharides, and fats), referred to stretching vibration of $\mathrm{C}-\mathrm{H}$ bond. Intensity of peaks in this region is increasing with duration of the experiment, especially with MBR B, which may be explained by adsorption of petroleum compounds.

In case of MBR B spectra also observed mid intensity peaks on $1700 \mathrm{~cm}^{-1}$, which reflect stretching $\mathrm{C}=\mathrm{O}$ vibration in petroleum compounds: aliphatic ketones-1695-1730 $\mathrm{cm}^{-1}$; aromatic aldehydes $-1690-1720 \mathrm{~cm}^{-1}$; aliphatic-aromatic ketones $-1675-1700 \mathrm{~cm}^{-1}$; and amides $-1630-1700 \mathrm{~cm}^{-1}$. In some samples, this region is masked by other, much more intense bands.

In region $1650 \mathrm{~cm}^{-1}$, the mostly intense absorption band in the whole spectra is observed. This signal reflects stretching, asymmetrical vibrations of $\mathrm{COO}^{-}$and is characteristic for peptides and proteins.

Next band occurs in $1535 \mathrm{~cm}^{-1}$. It is a sharp, intense peak reflecting corresponding symmetrical vibrations of $\mathrm{NH}^{+}$bond, characteristic for proteins. Relative intensity of this band is increasing with time of sampling. There can also be observed absorption bands near $1450 \mathrm{~cm}^{-1}$ : monosaccharides (deforming $\mathrm{C}-\mathrm{H}$ bond vibration), ring, aromatic (mid-intense, 1465-1430 $\mathrm{cm}^{-1}$ ), alkenes (C-H functional group), and amides ( $\mathrm{N}-\mathrm{H}$ group).

In wave number $1245 \mathrm{~cm}^{-1}$, region of deforming vibration of $\mathrm{NH}^{+}$, absorption band is also observed. This reflects also peptides and proteins and increase of the intensity may be explained by adsorption of them on surface of the activated sludge or indicating the secretion of the extracellular polymeric substances.

The last analyzed region is $1060 \mathrm{~cm}^{-1}$, characteristic for $\mathrm{C}-\mathrm{O}$ bond stretching vibration in glycerol. Occurrence of this peak is an evidence of fats and fatty acids presents in the sample.

Figure 1 shows spectra profile obtained from MBR A (control) and MBR B (working reactor) samples from the final of the experiment.

Summing up, both samples (obtained from MBR A and MBR B) contained peptides and proteins, carbohydrates, fats, and aliphatics. As a reason for the analogies stated that both reactors were inoculated with the same activated sludge 
Table 2 Library for analysis of the activated sludge composition

\begin{tabular}{|c|c|c|c|c|c|}
\hline Wave number $\left(\mathrm{cm}^{-1}\right)$ & Shape & Intensity & Bond & Compound(s) & Class \\
\hline $3650-3200$ & $\begin{array}{l}b \\
b \\
b \\
b \\
b\end{array}$ & $\begin{array}{l}\mathrm{str} \\
\mathrm{m} \\
\mathrm{m} \\
\mathrm{m} \\
\mathrm{m}\end{array}$ & st O-H & $\begin{array}{l}\text { Glycerol } \\
\text { Glucose } \\
\text { Lactose } \\
\text { Sucrose } \\
\text { Phenol }\end{array}$ & $\begin{array}{l}\text { Polyalcohol } \\
\text { Monosaccharide } \\
\text { Sacharide } \\
\text { Saccharide } \\
\text { phenols }\end{array}$ \\
\hline $3300-2800$ & $\begin{array}{l}\mathrm{b} \\
\mathrm{b} \\
\mathrm{b} \\
\mathrm{b}\end{array}$ & $\begin{array}{l}\mathrm{m} \\
\mathrm{m} \\
\mathrm{m} \\
\mathrm{m}\end{array}$ & st $\mathrm{NH}_{3}\left(\mathrm{~N}^{+}-\mathrm{H}\right)$ & $\begin{array}{l}\text { Albumin } \\
\text { Ammonium sulphate } \\
\text { Dry meat extract } \\
\text { Peptone G }\end{array}$ & $\begin{array}{l}\text { Protein } \\
\text { Ammonium } \\
\text { Peptide } \\
\text { Peptide }\end{array}$ \\
\hline $3000-2840$ & $\begin{array}{l}\mathrm{s}(\mathrm{m}) \\
\mathrm{s}(\mathrm{m}) \\
\mathrm{s}(\mathrm{m}) \\
\mathrm{s}(\mathrm{m})\end{array}$ & $\begin{array}{l}\mathrm{str} \\
\mathrm{m} \\
\mathrm{m} \\
\mathrm{w}\end{array}$ & st $\mathrm{C}-\mathrm{H}$ & $\begin{array}{l}\text { Glycerol } \\
\text { Glucose } \\
\text { Oleic acid } \\
\text { Sucrose }\end{array}$ & $\begin{array}{l}\text { Polyalcohol } \\
\text { Monosaccharide } \\
\text { Fats } \\
\text { Sacharide }\end{array}$ \\
\hline 2900 & $\mathrm{~s}$ & $\mathrm{w}$ & & Lactose & Sacharide \\
\hline 2360 & $\mathrm{~s}$ & w & st $\mathrm{NH}^{+}$ & Ammonium sulphate & Ammonium \\
\hline 2075 & $\mathrm{~s}$ & str & $\mathrm{C} \equiv \mathrm{N}$ & Potassium cyanide & Cyanides \\
\hline 2045 & $\mathrm{~s}$ & str & $\mathrm{SC} \equiv \mathrm{N}$ & Potassium thiocyanate & Thiocyanides \\
\hline 1775 & $\mathrm{~s}$ & w & st $\mathrm{C}=\mathrm{O}$ & Sodium carbonate & Carbonates \\
\hline 1710 & $\mathrm{~s}$ & str & & Oleic acid & Fats \\
\hline 1680 & $\mathrm{~s}$ & str & st $\mathrm{C}=\mathrm{C}$ & Phenol & Phenols \\
\hline 1655 & $\mathrm{~s}$ & str & st as $\mathrm{COO}^{-}$ & Albumin & Protein \\
\hline $1650-1575$ & $\mathrm{~s}(\mathrm{~m})$ & str & & Dry meat extract & Peptide \\
\hline 1600 & $\mathrm{~s}$ & str & & Peptone G & Peptide \\
\hline 1570 & $\mathrm{~s}$ & w & $\operatorname{def} \mathrm{NH}_{2}$ & Ammonium sulphate & Ammonium \\
\hline 1535 & $\begin{array}{l}\mathrm{s} \\
\mathrm{s}\end{array}$ & $\begin{array}{l}\text { str } \\
\text { str }\end{array}$ & sy $\mathrm{NH}_{3}^{+}$ & $\begin{array}{l}\text { Albumin } \\
\text { Peptone G }\end{array}$ & $\begin{array}{l}\text { Protein } \\
\text { Peptide }\end{array}$ \\
\hline 1515 & $\mathrm{~s}$ & str & & Dry meat extract & Peptide \\
\hline 1460 & $\begin{array}{l}\mathrm{s} \\
\mathrm{s}\end{array}$ & $\begin{array}{l}\text { str } \\
\text { str }\end{array}$ & st $\mathrm{C}=\mathrm{O}$ & $\begin{array}{l}\text { Sodium carbonate } \\
\text { Acid sodium carbonate }\end{array}$ & $\begin{array}{l}\text { Carbonates } \\
\text { Carbonates }\end{array}$ \\
\hline $1445-1350$ & $\begin{array}{l}\mathrm{s} \\
\mathrm{s} \\
\mathrm{s}\end{array}$ & $\begin{array}{l}\mathrm{m} \\
\mathrm{m} \\
\mathrm{m}\end{array}$ & def C-H (skelet) & $\begin{array}{l}\text { Glucose } \\
\text { Lactose } \\
\text { Sucrose }\end{array}$ & $\begin{array}{l}\text { Monosaccharide } \\
\text { Sacharide } \\
\text { Sacharide }\end{array}$ \\
\hline 1440 & $\mathrm{~s}$ & $\mathrm{~m}$ & $\operatorname{def} \mathrm{CH}_{2}$ & Oleic acid & Fats \\
\hline 1410 & $\mathrm{~s}$ & str & $\mathrm{CH}_{2}$ & Glycerol & Polyalcohol \\
\hline 1400 & $\mathrm{~s}$ & str & $\mathrm{S}(=\mathrm{O})_{2}\left(\mathrm{SO}_{4}\right)$ & Ammonium sulphate & Ammonium \\
\hline 1400 & $\mathrm{~s}$ & str & $\operatorname{def} \mathrm{NH}_{3}$ & Dry meat extract & Peptide \\
\hline 1380 & $\mathrm{~s}$ & str & $\mathrm{N}=\mathrm{O}$ & Sodium nitrate & Nitrate \\
\hline 1270 & $\mathrm{~s}$ & $\mathrm{~s}$ & st $\mathrm{NO}_{2}$ & Sodium nitrite & Nitrite \\
\hline 1255 & $\mathrm{~s}$ & $\mathrm{~m}$ & $\operatorname{def} \mathrm{NH}_{3}$ & Peptone G & Peptide \\
\hline 1245 & $\mathrm{~s}$ & $\mathrm{~m}$ & & Albumin & Protein \\
\hline 1235 & $\mathrm{~s}$ & $\mathrm{~m}$ & $\operatorname{def} \mathrm{C}=\mathrm{O}$ & Oleic acid & Fats \\
\hline 1135 & $\begin{array}{l}\mathrm{s} \\
\mathrm{s} \\
\mathrm{s}\end{array}$ & $\begin{array}{l}\mathrm{s} \\
\mathrm{s} \\
\mathrm{s}\end{array}$ & st $\mathrm{S}=\mathrm{O}(\mathrm{R}-\mathrm{SO}-\mathrm{OR})$ & $\begin{array}{l}\text { Sodium sulphate } \\
\text { Sodium sulphite } \\
\text { Sodium thiosulphate }\end{array}$ & $\begin{array}{l}\text { Sulphate } \\
\text { Sulphite } \\
\text { Thiosulphate }\end{array}$ \\
\hline $1100-1040$ & $\mathrm{~s}(\mathrm{~m})$ & $\mathrm{s}$ & st $\mathrm{C}-\mathrm{O}$ & Glycerol & Polyalcohol \\
\hline 1100 & $\mathrm{~s}$ & $\mathrm{~s}$ & st $\mathrm{Si}-\mathrm{O}$ & Sodium silicate & Silicate \\
\hline $1100-1000$ & $\begin{array}{l}\mathrm{s}(\mathrm{m}) \\
\mathrm{s}(\mathrm{m})\end{array}$ & $\begin{array}{l}\mathrm{s} \\
\mathrm{s}\end{array}$ & st CO & $\begin{array}{l}\text { Lactose } \\
\text { Sucrose }\end{array}$ & $\begin{array}{l}\text { Sacharide } \\
\text { Sacharide }\end{array}$ \\
\hline 1075 & $\mathrm{~s}$ & w & $\mathrm{S}=\mathrm{O}$ & Ammonium sulphate & Ammonium \\
\hline 1015 & $\mathrm{~s}$ & $\mathrm{~s}$ & $\mathrm{C}-\mathrm{O}\left(\mathrm{CH}_{2}-\mathrm{OH}\right)$ & Glucose & Monosaccharide \\
\hline
\end{tabular}

$b$ broad band, $s$ sharp band, $s(m)$ multiple sharp band, $s t r$ strong intensity band, $m$ medium intensity band, $w$ weak intensity band, st stretching vibration, st as stretching asymmetric vibration, def deforming vibration, sy symmetrical vibration, skelet skeletal vibration 
Fig. 1 Spectra profile obtained from MBR A (control) and MBR B (working reactor) samples from the late stage of the experiment

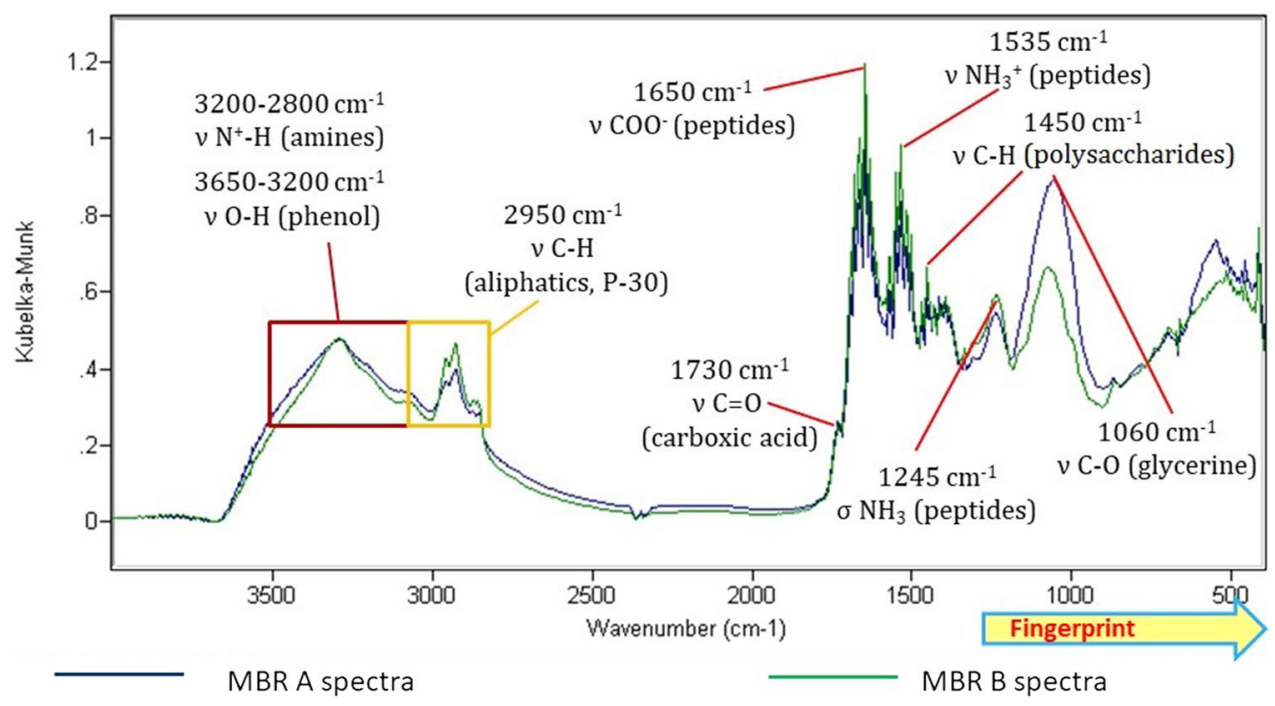

(municipal WWTP in Zabrze). Moreover, the only difference in the fed for the reactors was dosing petroleum compounds to the MBR B broth. Differences are visible not so much in position of the absorption bands, but in their relative intensity (according to the methodology, Kubelka-Munk method allows to indirectly assess the changes in concentration by comparing the intensity). It can be concluded that dosing petroleum compounds to the reactor's feed cause occurring changes in FT-IR spectra of the activated sludge, especially in regions $2950 \mathrm{~cm}^{-1}$-aliphatics; $1700 \mathrm{~cm}^{-1} \mathrm{C}=\mathrm{O}$ bond region and $1060 \mathrm{~cm}^{-1}$. Due to used transformation methods (Kubelka-Munk), those intensity changes can be quasiquantitatively assessed. Higher peak in the region $2950 \mathrm{~cm}^{-1}$ clearly reflects adsorption of aliphatic compounds on the activated sludge.

The results of FT-IR analysis of lyophilized activated sludge suggest that the presence of characteristic absorption peaks of peptides, lipids, polymeric substances, and carboxylic acids may be referred to presence of functional groups in the microorganism's organelles and EPS (Extracellular Polymeric Substances) (Gulnaz et al. 2006; Liu and Fang, 2002).

Similar experiment concerning analysis of the FT-IR spectra of activated sludge treating wastewater containing phenols, the appearance of absorption peaks in range 2124$2082 \mathrm{~cm}^{-1}$ was observed (Wharfe et al. 2010). The intense of the peak was increasing during the study period, what may be result of adsorption of phenol and/or its metabolites on the surface of flocks. Moreover, the absorption peaks in range 1754-1710 $\mathrm{cm}^{-1}$ were observed. Probably, it was connected with vibration of $\mathrm{C}=\mathrm{O}$ bonds characteristic for carboxylic groups and metabolism of phenol by activated sludge with cleavage of benzene ring. The presence of phenol in wastewater might influence the chemical composition of activated sludge. Other studies concerning investigation of marine plant exposed to petrol and diesel changes in metabolic profile revealed that there were visible changes in FT-IR spectra of plants exposed and non-exposed to xenobiotics (Pilatti et al. 2017).

Studies concerned the comparison of biomass collected from different types of wastewater-treating systems (fixedfilm activated sludge, moving bed biofilm reactor, and membrane bioreactor), defined as effectiveness of acid extractable fraction removal; measuring was performed also using FT-IR technique. Revealed that there are differences between specific treating systems, depending on attached biomass (Huang et al. 2017). Another experiment concluded that there are notable variations in relative intensities of several characteristic absorption bands of functional groups among different treated wastewaters, and FT-IR spectra were comparable to those obtained in recent study (Yang et al. 2015).

In experiments conducted by Cheftez et al. (2006), the IR spectra of fraction showing sorption properties to aromatic hydrocarbons were studied. The tested substances were presenting hydrophobic neutral (HoN) and hydrophobic acid (HoA) features. The neutral compounds showed higher sorption properties than the acid compounds. Spectra of both substances differ by the presence of intense absorption peak wavenumbers 1720 and $1650 \mathrm{~cm}^{-1}$ in the HoA spectrum and its absence in the HoN spectrum. The range of wavenumber is characteristic to vibration of $\mathrm{C}=\mathrm{O}$ bonds, what may be referred to the presence of carboxyl group $\mathrm{COOH}$. In the other ranges of frequency, spectra are similar in shape. Zhang et al. (2009) revealed that FT-IR analysis may be used to evaluate the degradation of extracellular substances and suspensions (EBOM-extracellular biological organic matter) by cells capable of generating electricity (MFC-microbial fuel cell).

In other studies (Jiang et al. 2010), spectra of four substances were compared. The changes in the intensity of 
absorption bands as a measure of biodegradation rate were determined. The results show that fractions containing aliphatic fragments, of secondary amides, carbohydrates, and hydrocarbons were biodegradable. However, the compounds containing aromatic components were not hydrolyse and biodegradable by MFC cell system.

Summarizing, the FT-IR technique appears to be useful in monitoring changes in composition in activated sludge and other media, such as soil. Performing FT-IR analysis of samples provides useful indicators to characterize changes in organic matters, without the need of extraction procedures (Bernier et al. 2013). This analytical approach is simple, cheap and efficient in applications aimed to determine changes in investigated media (Pilatti et al. 2017).

\section{Conclusions}

The obtained results found that fast and reliable analysis of the activated sludge chemical character using FT-IR technique is possible.

- Analysis of the activated sludge spectra based on the prepared correlation table is fast and reliable method.

- Analysis conducted using personally developed correlation table provides clear and reliable results, corresponding to the results obtained in similar experiments.

- Activated sludge can be identified for the type of treated wastewater based on the presented methodology, using the FT-IR technique.

- Changes occurring in the chemical structure of the activated sludge treating petroleum wastewater are visible in the obtained spectra, and can be explained using FT-IR analysis.

Acknowledgements This work was partially supported by the Ministry of Science and Higher Education (Poland), Project BK-217/RIE8/16.

Open Access This article is distributed under the terms of the Creative Commons Attribution 4.0 International License (http://creativeco mmons.org/licenses/by/4.0/), which permits unrestricted use, distribution, and reproduction in any medium, provided you give appropriate credit to the original author(s) and the source, provide a link to the Creative Commons license, and indicate if changes were made.

\section{References}

Amir S, Jouraiphy A, Meddich A, El Gharous M, Winterson P, Hafdi M (2010) Structural study of humic acids during composting of activated sludge-green-waste: elemental analysis, FTIR and ${ }^{13} \mathrm{C}$ NMR. J Hazard Mater 177:524-529. https://doi.org/10.1016/j. jhazmat.2009.12.064
Bernier HM, Levy GJ, Fine P, Borisover M (2013) Organic matter composition in soils irrigated with treated wastewater: FT-IR spectroscopic analysis of bulk soil samples. Geoderma 209-210:233240. https://doi.org/10.1016/j.geoderma.2013.06.017

Cheftez B, Ilani T, Schulz E, Chorover J (2006) Wastewater dissolved organic matter: characteristics and sorptive capabilities. Water Sci Technol 53:51-57. https://doi.org/10.2166/wst.2006.207

Cygański A (2002) Spectroscopic methods in analytical chemistry. Wydawnictwa Naukowo-Techniczne, Warszawa. ISBN 83-204-1876-3

Delaunay D, Rabiller-Baudry M, Gozálvez-Zafrilla JM, Balannec B, Frappart M, Paugam L (2008) Mapping of protein fouling by FTIR-ATR as experimental tool to study membrane fouling and fluid velocity profile in various geometries and validation by CFD simulation. Chem Eng Process 47:1106-1117. https://doi. org/10.1016/j.cep.2007.12.008

Dias AMA, Moita I, Páscota R, Alves MM, Lopes JA, Ferreira EC (2008) Activated sludge process monitoring through in situ NIR spectral analysis. Water Sci Technol 57:1643-1650. https://doi. org/10.2166/wst.2008.147

Džimbeg-Malčić V, Barbarić-Mikočević Ž, Itrić K (2011) KubelkaMunk theory in describing optical properties of paper(I). Tehnički vjesnik-Technical. Gazette 18:117-124

Guibaud G, Tixier N, Bouju A, Baudu M (2003) Relation between extracellular polymers' composition and its ability to complex $\mathrm{Cd}$, $\mathrm{Cu}$ and $\mathrm{Pb}$. Chemosphere 52:1701-1710. https://doi.org/10.1016/ S0045-6535(03)00355-2

Gulnaz O, Kaya A, Dincer S (2006) The reuse of dried activated sludge for adsorption of reactive dye. J Hazard Mater 134:190-196. https ://doi.org/10.1016/j.jhazmat.2005.10.050

Huang C, Shi Y, Xue J, Zhang Y, El-Din MG, Liu Y (2017) Comparison of biomass from integrated fixed-film activated sludge (IFAS), moving bed biofilm reactor (MBBR) and membrane bioreactor (MBR) treating recalcitrant organics: importance of attached biomass. J Hazard Mater 326:120-129. https://doi.org/10.1016/j. jhazmat.2016.12.015

Hunter Lab (2008) The Kubelka-Monk theory and K/S. Vol. 18, No.7 https://www.hunterlab.se/wp-content/uploads/2012/11/The-Kubel ka-Monk-Theory-and-K-S.pdf. Accessed 31 Oct 2017

Jiang J, Zhao Q, Wei L, Wang K (2010) Extracellular biological organic matters in microbial fuel cell using sewage sludge as fuel. Water Res 44:2163-2170. https://doi.org/10.1016/j.watres.2009.12.033

Jiao Y, Cody GD, Harding AK, Wilmes P, Schrenk M, Wheeler KE, Banfield JF, Thelen MP (2010) Characterization of extracellular polymeric substances from acidophilic microbial biofilms. Appl Environ Microbiol 76(9):2916-2922. https://doi.org/10.1128/ AEM.02289-09

Kang SY, Kim DW, Kim KW (2007) Enhancement of As(V) adsorption onto activated sludge by methylation treatment. Environ Geochem Hlth 29:313-318. https://doi.org/10.1007/s10653-007-9096-y

Kim B, Gautier M, Michel P, Gourdon R (2013) Physical-chemical characterization of sludge and granular materials from a vertical flow constructed wetland for municipal wastewater treatment. Wat Sci Tech 68(10):2257-2263. https://doi.org/10.2166/wst.2013.485

Liu H, Fang HHP (2002) Extraction of extracellular polymeric substances (EPS) of sludges. J Biotechnol 95:249-256. https://doi. org/10.1016/S0168-1656(02)00025-1

Mazurkiewicz R, Salwińska E (2000) Infrared specroscopy. In: Zieliński W, Rajca A (eds) Spectroscopic methods and their use for the identification of organic compounds. Wydawnictwa Naukowo-Techniczne, Warszaw. ISBN 83-204-2479-8

Parolo ME, Savini MC, Loewy RM (2017) Characterization of soil organic matter by FT-IR spectroscopy and its relationship with chlorpyrifos sorption. J Environ Manage 196:316-322. https:// doi.org/10.1016/j.jenvman.2017.03.018 
Pereira MR, Yarwood J (1996) ATR-FTIR spectroscopic studies of the structure and permeability of sulfonated poly(ether sulfone) membranes. J Chem Soc Faraday T 92:2731-2735. https://doi. org/10.1039/FT9969202731

Pilatti KF, Ramlov F, Schmidt EC, Costa C, de Oliveira ER, Bauer CM, Rocha M, Bouzon ZL, Maraschin M (2017) Metabolomics of Ulva lactuca Linnaeus (Chlorophyta) exposed to oil fuels: Fourier transform infrared spectroscopy and multivariate analysis as tools for metabolic fingerprint. Mar Pollut Bull 114:831-836. https:// doi.org/10.1016/j.marpolbul.2016.11.006

Pretsch E, Bühlmann P, Affolter C (2000) Structure determination of organic compounds - tables of spectral data. Springer, Berlin Heidelberg. ISBN 978-3-540-93810-1

Quilès F, Humbert F, Delille A (2010) Analysis of changes in attenuated total reflection FTIR fingerprints of Pseudomonas fluorescens from planktonic state to nascent biofilm state. Spectrochim Acta 75:610-616. https://doi.org/10.1016/j.saa.2009.11.026

Reed JP, Devlin D, Esteves SRR, Dinsdale R, Guwy AJ (2011) Performance parameter prediction for sewage sludge digesters using reflectance FT-NIR spectroscopy. Water Res 45(8):2463-2472. https://doi.org/10.1016/j.watres.2011.01.027

Sarraguça MC, Paulo A, Alves MM, Dias AMA, Lopes JA, Ferreira EC (2009) Quantitative monitoring of an activated sludge reactor using on-line UV-visible and near-infrared spestroscopy. Anal Bioanal Chem 395:1159-1166. https://doi.org/10.1007/s0021 6-009-3042-z

PIKE Technologies (2009) Diffuse reflectance-theory and applications. https://www.piketech.com/files/pdfs/PIKE_Diffuse-Refle ctance-Theory-Applications.pdf. Accessed 31 Oct 2017
Wharfe ES, Jarvis RM, Winder CL, Whiteley AS, Goodacre R (2010) Fourier transform infrared spectroscopy as a metabolite fingerprinting tool for monitoring the phenotypic changes in complex bacterial communities capable of degrading phenol. Environ Microbiol 12:3253-3326. https://doi.org/10.111 $1 /$ j.1462-2920.2010.02300.x

Wiszniowski J, Ziembińska A, Ciesielski S (2011) Removal of petroleum pollutants and monitoring of bacterial community structure in a membrane bioreactor. Chemosphere 83:49-56. https://doi. org/10.1016/j.chemosphere.2010.12.092

Yang L, Ho Han D, Lee B-M, Hur J (2015) Characterizing treated wastewaters of different industries using clustered fluorescence EEM-PARAFAC and FT-IR spectroscopy: implications for downstream impact and source identification. Chemosphere 127:222228. https://doi.org/10.1016/j.chemosphere.2015.02.028

Zeng J, Gao J-M, Chen Y-P, Yan P, Dong Y, Shen Y, Guo J-S, Zeng $\mathrm{N}$, Zhang P (2016) Composition and aggregation of extracellular polymeric substances (EPS) in hyperhaline and municipal wastewater treatment plants. Sci Rep 6:1-9. https://doi.org/10.1038/ srep26721

Zhang H, Qu J, Liu H, Zhao X (2009) Characterization of isolated fractions of dissolved organic matter from sewage treatment plant and the related disinfection by-products formation potential. J Hazard Mater 164:1433-1438. https://doi.org/10.1016/j.jhazm at.2008.09.057 